\title{
GODORT Annual Conference Highlights
}

\section{Membership Update}

Following a welcome and introductions, GODORT Chair Shari Laster gave a brief progress report on the migration of content from the GODORT wiki to the ALA website. Treasurer Rebecca Hyde also presented the most recent Treasurer's Report. The organization's overall financial outlook is good, although the reception costs were higher for New Orleans without a corresponding increase in fundraising.

Councilor Bill Sudduth reported on ALA Council activity at the Annual Conference. The Organizational Effectiveness review addresses two questions: (1) what would you fix in ALA? and (2) if you were creating an organization today, what would you do? He asked that GODORT endorse the "Resolution to Honor African Americans Who Fought Library Segregation," which was done unanimously. Bylaws Coordinator Vicki Tate presented two proposed Bylaws changes, which were approved by membership (discussed below). The chair of Legislation Committee, Geoff Swindells, moved that membership endorse in principle "Resolution Recognizing the 25th Anniversary of the GPO Access Act and Calling for the Enactment of the FDLP Modernization Act," which was unanimously approved.

GODORT Chair Shari Laster discussed the conclusion of GODORT's reorganization process; these remarks will be published as the chair's column in the Summer 2018 issue of DttP. Geoff Swindells gave an update of Washington Office's recent work regarding H.R. 5305, "The FDLP Modernization Act of 2018.”-Shari Laster, GODORT Chair

\section{Steering Committee}

Discussion continued about the ALA Organizational Effectiveness review. GODORT Chair Shari Laster will serve on a Round Table Coordinating Assembly task force to provide feedback for this process. The chair of Cataloging Committee, Andrea Morrison, asked that the Chair sign a letter to the Government Publishing Office requesting public progress reports on addressing PURLs that are no longer working due to changes in web security requirements. The motion carried unanimously, and a letter will be drafted.

Natasha Arguello gave an overview of a juried program proposal for Annual 2019 that the Business Reference and Services Section (BRASS) will formally submit to GODORT for consideration as a cosponsored-in-name-only program. GODORT Chair Shari Laster reported that she is working with GODORT Emerging Leader Kenya Flash and Social Responsibilities Round Table (SRRT) Coordinator Kenny Garcia to develop a juried program proposal for Annual 2019 on Census 2020. She requested that Steering approve up to $\$ 1,500$ for honoraria, which carried unanimously. On behalf of Chair-Elect Hallie Pritchett, Shari Laster presented the slate of nominees for 2018/2019 GODORT officers. The slate was unanimously approved.

Following membership's endorsement of "Resolution to Honor African Americans Who Fought Library Segregation," Chair Shari Laster noted that the sixth Resolved reads that ALA "will review policy documents and internal procedures to ensure Equity, Diversity, and Inclusion (EDI) principles are reflected throughout." She proposed the creation of a GODORT Ad Hoc Working Group on Equity, Diversity, and Inclusion (EDI), to review GODORT's policies and procedures to improve adherence to EDI principles, which was unanimously approved. The group will provide an initial report to Steering by the 2019 Midwinter Meeting, and will recommend action items. The final report will be due by the 2019 Annual Conference, at which time the group will dissolve. Initial volunteers came from those assembled at Steering, and a call will be put forth to membership for participation.

James Jacobs proposed that the chair write a letter to the Librarian of Congress to thank the Library and the Congressional Research Service for their work on providing open access to CRS Reports. The letter will also serve to encourage them to continue to develop tools in conjunction with their users. This proposal was unanimously approved.-Shari Laster, GODORT Chair

\section{Awards Committee}

The Awards Committee extends congratulations to the 2018 GODORT Awardees! (https://wikis.ala.org/godort /index.php/Announcing_the_2018_ GODORT_Awards_Winners):

- James Bennett Childs Award: Karen M. Russ

- ProQuest/GODORT/ALA "Documents to the People" Award: Rosemary L. Meszaros

- Bernadine Abbott Hoduski Founders Award: Marilyn Von Seggern

- Larry Romans Mentorship Award: Courtney L. Young 
- Margaret T. Lane/Virginia F. Saunders Memorial Research Award: Robert Lopresti, for his book, When Women Didn't Count: The Chronic Mismeasure and Marginalization of American Women in Federal Statistics (Praeger, 2017)

- GODORT-Sponsored American Library Association Emerging Leader: Kenya S. Flash

- W. David Rozkuszka Scholarship: Susie O'Connor

- NewsBank/Readex/GODORT/ ALA Catharine J. Reynolds Research Grant: Hayley Johnson and Sarah Simms

The committee met in a closed meeting at ALA Annual to discuss plans for the 2018 Awards Reception, held on Sunday June 24 from 6 to 8 pm at the Louisiana Supreme Court Building, 1st Floor, 400 Royal Street. The committee also discussed the 2017-18 year and plans for 2018-19._Ann Marshall, Chair

\section{Bylaws Coordinator}

This spring there were two changes for the GODORT Bylaws that were presented to Steering Committee for consideration: (1) dropping the first Steering Committee at conferences and (2) reducing the number of elected positions on committees. The rationale for the first change was because of the increase use of virtual meetings for the Steering Committee and because of the reduction of meeting times available through ALA conference scheduling. The rationale for the second change was to simplify the recruitment process for most of the positions within the committee structure and to increase the opportunities for volunteers to serve in leadership roles.
The initial wording for the proposed changes in the Bylaws was presented to the Executive Committee which then recommended forwarding the proposed changes to the Steering Committee for discussion. After some suggestions were made, the final proposed wording was formally presented to the Steering Committee for a vote on June 6. It was recommended by the Committee, with a vote of 11 in favor, 1 opposed, and 5 not voting, to bring the proposed changes before the general membership at the Annual Conference. The text of the proposed Bylaw changes was posted on the wiki and communicated to the members through the GODORT listserv. A notice regarding the upcoming vote at ALA Annual conference was also posted on GOVDOC-L.

At the GODORT Membership Update meeting, both proposals for Bylaws changes were presented. Each proposal was decided separately with discussion from the membership on both issues. The first proposal was passed with two votes in opposition. The second proposal was passed with no opposing votes.

The updated Bylaws will be posted on the wiki until the new GODORT web site is ready. All Policies and Procedures Manual (PPM) chapters will be reviewed for necessary changes to comply with the adopted changes in the Bylaws. As of the summer of 2018, almost all PPM chapters have been updated in the last year with current information. Only six chapters remain "under review."-Vicki Tate, GODORT Bylaws and Organization Coordinator

\section{Cataloging Committee}

The Cataloging Committee is working on moving the Toolboxes for Processing and Cataloging Government Documents to the GODORT LibGuides. The federal toolbox is in draft and will be completed later in 2018; work is beginning on the international toolbox. Volunteers are needed for editing the guides. Stephen Kharfen gave the Government Publishing Office report and chair Andrea Morrison commended GPO for their excellent cataloging partnerships and projects. Of special note is the new copyright statement that will be updated globally in existing bibliographic records in the Catalog of US Government Publications (CGP) in MARC21 field 542. The Committee asked GPO for public progress reports on the scope and progress of the project updating CGP record links to IT security standards, especially because of the effect of broken links on users.

Jim Noel gave the MARCIVE report. The chair also updated the Committee on progress with the GODORT website migration and the Committee agreed that the new website should link to the new LibGuides, not to the Toolboxes on the wiki. Michael Alguire gave a written report that summarized continuing education in cataloging initiatives and the committee agreed to work on a webinar and infographic covering federal government thesauri and vocabularies.-Andrea Morrison, Chair

\section{Education Committee}

Members and guests at the Education Committee meeting discussed the development of a proposal for an Emerging Leaders project with GODORT's Emerging Leader, Kenya Flash. The committee will move forward to develop a proposal for a civic engagement toolkit for libraries.

The Government Information Online (GIO) virtual reference service now has seventeen volunteers. A schedule will be created to ensure that questions are monitored and distributed 
among the volunteers. GIO receives about ten questions per week that are received via direct patron input or are forwarded from the Government Publishing Office's AskGPO.

Migration of documents from the GODORT Wiki is continuing. The Education Committee discussed the status of the GODORT Handout Exchange, which contains many outdated guides and broken links to external sites.

The decline in the number of LIS programs that offer government information courses continues to be a matter of concern. The Education Committee is considering surveying LIS programs that do not offer such courses to understand why. At the same time, the committee is exploring alternatives to LIS courses to educate librarians about government information, such as developing Open Educational Resources and online tutorials beyond what is available through the FDLP Academy and the "Help! I'm an Accidental Government Information Librarian" webinars._Gwen Sinclair, Chair

\section{Federal Information Interest Group (FIIG)}

FIIG hosted a varied discussion with topics ranging from strategies for approaching a mandated reduction in a government documents collection to the availability of up-to-date information on federal government websites.-Justin Otto, Interest Group Leader

\section{Government Information for Children (GIC) Committee}

The Government Information for Children (GIC) Committee met in New Orleans at ALA Annual. The committee began with a discussion about possibly producing brief video tutorials on government information. These would be short, focused videos aimed at teachers and librarians. The committee also discussed the ongoing migration of the GIC LibGuides from the University of Central Florida site to the GODORT LibGuide site. The guides will have an updated look and include lesson plans, links to national educational standards, and scope notes for all suggested government sites. The GIC LibGuides site can be found at http://godort.libguides .com/?group_id=16537.—Liza Weisbrod, Chair

\section{International Documents Task Force (IDTF)}

Representatives from the OECD, United Nations, World Bank, and International Monetary Fund joined a full room to discuss recent updates. Ramona Kohrs, head of the United Nations (UN) Depository Library Program, and Thanos Giannakopoulos, Chief of the United Nations Dag Hammarskjöld Library, attended via Skype. Jim Church mentioned the GODORT Cataloging Committee's Toolbox for Processing and Cataloging International Government Documents needed updating and sought volunteers. There were no responses.

Vendors from the international organizations present gave updates and reports. Conversation then shifted towards international documents acquisition issues and strategies. It was noted that suggestions for vendors would be welcome because some users still read print documents. Vendors such as MEA/Hogarths and Mary Martin were suggested. Ramona Kohrs gave a brief report on the UN Depository with no substantial updates.

The conversation then shifted into the realm of Open Access (OA) and international organizations. Stephen Wyber, chair of advocacy at IFLA was in attendance and made a brief report urging librarians to advocate for IGO $\mathrm{OA}$ adoption. He shared a presentation (https://goo.gl/xAvBp9) that he and Kris Kasianovitz from Stanford University prepared about OA and copyright policies in international organizations. The situation can be best described as chaotic. Some international organizations such as the World Bank, UNESCO, and WIPO have embraced, either partially or completely, OA policies, such as Attribution 3.0 IGO (CC BY 3.0 IGO), a Creative Commons License designed especially for IGOs. Others have absurdly restrictive policies: for example, the International Energy Agency requires permission for users to link to their content. Sheri Aldis from UN Publications insisted that in order for OA to be adopted at the United Nations this would need to be proposed by member states. Stephen Wyber and Jim Church noted in the case of other representative international organizations this initiative had come through their respective Secretariats.-James Church, IDTF Coordinator-Elect

\section{Legislation Committee}

The joint meeting with the ALA Committee on Legislation's Government Information Subcommittee (COL-GIS) opened with an update on GPO operations by David Walls, the agency's preservation librarian. David announced the retirement of Andy Sherman as Acting Director of GPO at the end of June, the appointment of Chief Operating Officer Herb Jackson as acting director in his place, and the president's nomination of Robert C. Tapella as director of GPO. Walls then summarized the status of the FDLP Modernization Act of 2018 (H.R. 5305), including the Congressional Budget Office's positive scoring 
of the legislation, reviewed the agency's FY 2019 appropriations, and concluded with an overview of preservation priorities from GPO's 2016 National Plan and related preservation activities at the agency.

This was followed by a presentation by on recent developments at the National Archives and Records Administration (NARA), by Meg Phillips, external affairs liaison at NARA. After briefly discussing the agency's 2018-22 strategic plan, she focused much of her time on the work of the Office of Government Information Services (OGIS) and the National Historical Publications and Records Commission (NHPRC). The meeting concluded with a brief discussion of the latest draft of the "Tribute Resolution Honoring the 25th Anniversary of the GPO Access Act," during which some amended language was proposed. COL-GIS approved the resolution in principle.

At Legislation II, Geoff Swindells, chair, reviewed the work of the committee since the ALA Midwinter Meeting, with a focus on urging depository libraries in states with Senators serving on the Senate Committee on Rules and Administration to write letters supporting the FDLP Modernization Act of 2018 (H.R. 5305). The Rules Committee will have jurisdiction over the legislation in the Senate, should it pass the House. The committee's efforts were particularly successful in Missouri, home of Roy Blunt Jr., chair of the Senate Rules Committee; and Geoff thanked Marie Concannon (University of Missouri-Columbia), Rebecca Hyde (Saint Louis University), and Jennifer Peters (Rockhurst University) for ensuring that their library administrations wrote letters to Senator Blunt. This was followed by a discussion of continued advocacy around the bill following ALA Annual. In a related action item, the chair agreed to distribute to GODORT members information packets containing draft support letters and contact information for members and staff of the Senate Rules Committee, and other committees as appropriate.

This was followed by a brief discussion of the latest draft of the tribute resolution on the twenty-fifth anniversary of the GPO Access Act. The committee approved the revised draft to bring the resolution to the floor at the Membership Update. The meeting ended in a general discussion of GODORT's approach to the nomination of Robert C. Tapella as director of GPO. The consensus of those in attendance was that GODORT should focus on the future of the FDLP and GODORT's long-standing support of permanent, no-fee, public access to federal government information and that GODORT Legislation will develop materials and strategies to support this effort. In two related action items, the chair agreed to compile an information packet containing relevant GODORT resolutions and other documents on the FDLP; and will draft a resolution calendar, outlining important dates and other milestones in preparing resolutions for consideration by ALA Council._-Geoff Swindells, Chair

\section{Program Committee}

This year there were two great programs focused on government information. GODORT cosponsored "Endangered Government Information: Strategies to Protect Government Collections" with panelists: James R. Jacobs (Stanford University Library), Susan Paterson (University of British Columbia), and Amanda Wakaruk (University of Alberta). Jim
Church (University of California, Berkeley) acted as moderator on discussions that focused on unintended, and intended, consequences of the Canadian government moving to electronic only content and how Crown Copyright prevents organizations from capturing data.

The GODORT chair's program "Government Information for a Cynical Public" presented panelists Alicia Kubas (University of Minnesota), Yasmin Sokkar Harker (CUNY School of Law), and Allan Van Hoye (CU Boulder) who explored issues of trust, how millennials view government information, and inequality. Panelist promoted healthy skepticism as a tool for librarians and users dealing with the current information environment and the sometimes questionable reliability of government information.-Susanne Caro

\section{Rare and Endangered Government Publications (REGP) Committee}

REGP attendees discussed several issues, including the Congressional Budget Office Report regarding H.R. 5303, and current news stories related to the Presidential Records Act of 1978. The committee will develop a letter template for asking legislators to encourage the president to preserve his legacy and stop destroying documents that will give researchers insight into his presidency.

The committee also heard from representatives from GPO about upcoming initiatives including trainings, tools, and resources to help libraries with preservation and conservation efforts. A discussion followed about storage and environmental control with regard to microformats collections.-Aimee Slater, Co-Chair 